\title{
Condições de trabalho dos artesãos dos galpões dos bois-bumbás de Parintins
}

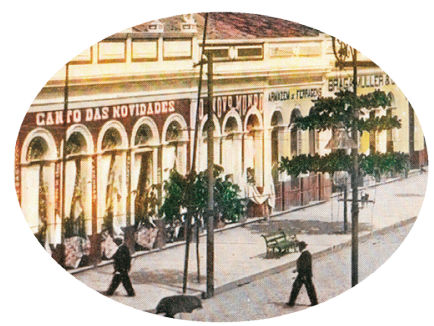

Rosângela de Oliveira Araújo*

\section{Resumo}

Este trabalho busca analisar as condições de trabalho dos artesãos dos galpões dos Bois-Bumbás Garantido e Caprichoso no bojo das relações de trabalho ditadas pela lógica da produção capitalista.

Palavras-chave: Indústria cultural; trabalho precarizado; festival folclórico; boi-bumbá.

\begin{abstract}
This paper seeks to analyze the working conditions of artisans of the sheds of the Bois-Bumbás Garantido and Caprichoso in the midst of labor relations dictated by the logic of capitalist production.
\end{abstract}

Keywords: Cultural industry; precarious work; folk festival; boi-bumbá.

* Bacharel em Serviço Social /UFAM; Especialista em Educação Ambiental para o Desenvolvimento Sustentável/ FSDB. 


\section{Introdução}

Esta pesquisa, que faz parte de minha monografia de conclusão de curso, pautou-se em analisar as condições de trabalho dos artesãos em suas atividades desenvolvidas nos galpões dos Bois-Bumbás Garantido e Caprichoso, no município de Parintins, tendo por base suas condições de vida.

O tema condições de trabalho dos artesãos do boi-bumbá passou a ser categoria central de análise, a partir do momento em que as Associações Folclóricas Garantido e Caprichoso incorporaram a lógica do sistema capitalista e, decorrente desta postura, as pessoas que anteriormente faziam e brincavam o boi por amor ao grupo folclórico, passaram a se integrar à produção como trabalhadores da indústria cultural.

O Festival Folclórico de Parintins tomou grandes proporções a partir do momento em que a festa se tornou um produto comercial. Nesse sentido, a Indústria Cultural está desempenhando brilhantemente o seu papel na venda do produto, tendo como patrocinadoras empresas nacionais e multinacionais, como também o governo do Estado e do município.

Nesse sentido, novas formas de fazer o boi-bumbá adequam-se à reestruturação produtiva do mundo globalizado e flexibilizado, onde o trabalho especializado se encontra em lugar de destaque, enquanto os de baixa qualificação disputam um lugar entre os trabalhadores precarizados.

Desse modo, buscou-se identificar os tipos de trabalhos realizados pelos artesãos nos galpões dos bois-bumbás de Parintins; detectar as condições nas quais os artesãos realizam suas atividades nos galpões; verificar como eles identificam suas condições de trabalho; e analisar qual a importância desse trabalho para esses artesãos na realidade de Parintins.

$\mathrm{Na}$ exposição dos dados coletados na pesquisa de campo procuramos identificar os entrevistados por letras do alfabeto, a fim de preservar a sua identidade.

\section{Perfil do trabalhador}

Ao verificar universo dos artesãos, observamos que a maior incidência é de trabalhadores do sexo masculino de modo que a nossa amostra está em consonância com o censo do IBGE de 2000 sobre a população de Parintins, 
que aponta a população economicamente ativa com dez anos ou mais de idade que possuem rendimento, os homens aparecem em maior número em relação às mulheres, sendo 17.787 do sexo masculino, e 10.046 do sexo feminino.

A idade dos artesãos varia de dezoito a sessenta e um anos de idade, porém, o maior índice é os de idade entre trinta a trinta e três anos. Esses dados confirmam os a pesquisa oficial do PME (Pesquisa Mensal de Emprego) do PEA (População Economicamente Ativa) do IBGE (Instituto Brasileiro de Geografia e Estatística), entre os anos de 95 e 96, sobre mercado de trabalho, no qual o desemprego que apresenta em queda de peso relativo para os trabalhadores de 25 a 39 anos, e aumento dos de 18 aos 24 anos, como também para os de 40 a 49 anos de idade.

Nesse aspecto, Silva e Vallina (2005: p.23), com base no DIEESE Departamento Intersindical de Estudos Socioeconômicos de 2001 observam que, a tendência do mercado brasileiro em geral dos trabalhadores, situa-se na faixa etária entre 20 e 40 anos.

Para Marx e Engels (2002: 20), acerca do trabalhador inserido no mercado de trabalho tendo que conviver com a realidade do trabalho industrial, como também a inserção da mão de obra feminina que substituiu a dos homens, fala que: "Diferenças de idade e de sexo não têm mais validade distintiva social para a classe trabalhadora. São todos instrumentos de trabalho, mais ou menos caros, para serem usados, de acordo com sua idade e sexo".

Dos artesãos que trabalham nos galpões dos bois-bumbás, noventa por cento são de Parintins e dez é oriundo de outras localidades próxima à cidade. Parintins é uma cidade na qual a veia artística é bastante acentuada, existindo inclusive uma brincadeira entre os parintinenses nesse aspecto, que "em Parintins as pessoas não nascem, estreiam". Por esse motivo é que a cidade supre suas próprias necessidades de trabalhadores para desenvolveram as atividades artísticas nos galpões.

Nesse sentido o artista identificado através da letra "C" comenta:

Hoje falo com certa facilidade da nossa terra, porque vi que não é só uma terra de boi-bumbá; é uma terra encantada, onde, se existe uma visão lírica que deslumbra as pessoas que vem fazer pesquisa e trabalhar. Sempre fazem a mesma pergunta: Como vocês construíram isso? 
Construímos com os nossos dons, com nossas mãos, com a nossa humildade, com a nossa capacidade de realizar com todos os alicerces que nos foi dado por Deus. E por ser uma cidade abençoada, uma cidade que tem mais de $7.000 \mathrm{Km}^{2}$, mas, que existe em cada metro um alicerce de conhecimento, seja na área artística, na música, na poesia, na escrita, seja na arte do inventismo. Não existe no mundo uma cidade comparada a Parintins.

Quanto ao estado civil, observa-se que, a metade dos artesãos é casada, e a outra está dividida entre solteiros e em união estável. Ë interessante o resultado desta pesquisa, no que tange ao estado civil, tendo com maior índice as pessoas casadas. Isso contraria o fato de que nos dias atuais as pessoas estão optando com maior intensidade em união estável.

Seguindo a perspectiva da existência de relação conjugal, no índice anteriormente citado, e diante da dinâmica de vida das famílias brasileiras, especificamente da amazonense percebe-se que, os que possuem dependentes seguem a tendência imposta pela ideologia capitalista, ou seja, de deixar velhos costumes de modelo de família extensa e constituir famílias com no máximo três filhos.

Quanto a existência de mais de uma pessoa que trabalha para complementar a renda da família, a metade desenvolve algum tipo de atividade. Essa modalidade vem de encontro com Bruschini (2000, p. 66), que "a família é uma unidade de produção, mas também de consumo onde predomina a divisão de tarefas de acordo com a idade, sexo, posição na família e escolaridade de cada indivíduo".

As famílias dos artesãos comungam desse ideário de produção e consumo e a metade que não está inserida no mercado de trabalho pode ser por fatores alheios à sua vontade. Essa tendência ao consumo e posteriormente ao individualismo, incutida ideologicamente pelos capitalistas, perpassa no meio das famílias contemporâneas, destruindo desta forma as relações anteriormente vivenciadas por elas. Segundo Marx e Engels (2002, p. 13), “a burguesia arrancou da família o véu sentimental e reduziu a relação familiar a uma mera relação de dinheiro".

Ao que se refere à renda familiar dos artesãos, a somatória dos sem rendimento, e menos de um salário mínimo que é de trinta por cento, iguala 
a quantidade dos que estão incluídos nos rendimentos de um a dois salários. Os que possuem rendimento de três a cinco salários mínimos são inferior ao total das variáveis acima mencionadas. Essas informações são confirmadas no resultado da amostra do censo demográfico/IBGE/2000 sobre rendimentos nominais no Município de Parintins. De acordo com os dados os maiores índices são de rendimento até um salário mínimo com 15.914 habitantes e os sem rendimento com 36.484 habitantes.

Os artesãos que trabalham no galpão dos bois quanto à escolaridade, a metade está inserida entre ensino médio, ensino fundamental incompleto e alfabetizado e os outros cinquenta por cento estão entre ensino médio e superior completo. Assim, metade dos artesãos não possui escolaridade mínima exigida pelo mercado de trabalho, que é o ensino médio completo.

A exigência por melhor qualificação é constatada diariamente nos jornais que circulam pelas cidades, nas páginas dos classificados sobre oferta de emprego. A esse respeito Pochmann (2000), Antunes (1995), Singer (2003), concordam ao falar que, a baixa qualificação do trabalhador, incorre como entrave para os mesmos adentrarem no mercado de trabalho.

Dessa forma, os trabalhadores com baixa renda, ficam desprovidos de se manter e de manter sua família, que acabam por serem usuários dos benefícios sociais promovidos a partir de políticas sociais.

Dos entrevistados, cinquenta por cento estão incluído no programa do Governo Federal Bolsa Família e somente um com aposentadoria por tempo de serviço, no entanto, este último considera ser benefício social, porém, a aposentadoria por tempo de serviço é um direito, e é assegurada em lei e pode ser constatada no Art. 201, $₫ 9^{\circ}$ da Constituição Federal Brasileira.

Os beneficiários do Programa do Governo Federal, Bolsa Família, no Título VIII Da Ordem Social, Capítulo II, Seção IV da assistência social, segundo o Art. 203 da Constituição preconiza: "A assistência social será prestada a quem dela necessitar independentemente de contribuição à seguridade social". Portanto, decorrente do estado de vulnerabilidade social, toda pessoa tem direito em ser assistido pelas políticas sociais.

Quanto a empregabilidade, a metade dos artesãos está empregada, a outra metade não possui vínculo empregatício; vivem na informalidade, fazendo "bicos". Nesta perspectiva é que Antunes (1995:148) comenta: "a classeque-vive-do-trabalho metamorfoseou-se". Com a reestruturação produtiva, 
passou-se a solicitar uma mão de obra mais especializada e de contrapartida o trabalhador sem as reais condições para se enquadrar neste mercado exigente passou a ficar a margem do trabalho formal e buscar alternativas de sobrevivência.

Dos entrevistados, ao que se refere a renda individual, quarenta por cento falam não terem rendimentos; vinte por cento possuem rendimento mensal de um a dois salários mínimos; vinte por cento, menos de um salário; dez por cento, de três a cinco salários e dez por cento não informou. Se compararmos essas informações com os dados de rendimento familiar pode-se perceber que o índice de pessoas sem rendimento aumentou. Isso pode denotar que esses que acresceram no percentual, podem estar sendo mantidos pela família, ou seja, aqueles que contribuem para renda familiar.

Portanto, a precariedade de condições de vida, pode estar no dia a dia da vida dessas pessoas, assim, dificuldade em encontrar trabalho formal é pontuada por Pochmann (2000, p. 42): “as novas regras do mercado de trabalho dificultou a entrada de novos trabalhadores, assim como também tem crescido uma relativa participação de jovens, mulheres e idosos no total dos excluídos que sentem dificuldades de encontrar um novo emprego".

A metade dos artesãos possui cursos profissionalizantes, sendo: técnico em Informática, Artes Plásticas, habilitação para o magistério, técnico em Patologia Clínica, Técnico em enfermagem. Tendo essa amostragem e comparando com os dados quanto ao rendimento mínimo, o percentual deveria ser compatível, no entanto, é menor o número de pessoas inseridas no mercado formal.

Portanto, no mercado de trabalho atual, no qual se exige um profissional flexível, multifuncional, polivalente, mesmo assim, ter qualificação não é garantia de se inserir no mercado formal de trabalho. Nesse sentido Antunes (1995, p. 45), comenta que: "O aumento do contingente de trabalhadores também contribuiu para a precarização do trabalho formal, a exploração do trabalho, os baixos salários, as longas jornadas de trabalho".

\section{Condições de trabalho dos artesões}

As pessoas que antes trabalhavam por amor ao boi e usufruíam o resultado de seu trabalho, passaram a buscar alternativas de sobrevivência, 
entre elas, o trabalho no interior dos galpões dos Bois-Bumbás Garantido e Caprichoso, onde, atualmente, são confeccionadas as fantasias, alegorias, e todo material necessário para construir o boi que será apresentado durante as três noites do festival.

O trabalho desenvolvido nos Bois-Bumbás de Parintins representa uma alternativa de trabalho para uma população sem muitas opções de emprego formal e com uma enorme desigualdade social, conforme informa os dados fornecidos pelo IBGE/2000.

Tendo em vista a escassez de oferta de emprego no município de Parintins e tendo como opção para a população o trabalho desenvolvido nos galpões, nos QG's (Quartéis-Generais), nos ateliês e em todos os setores destinados para a construção do "boi de arena" (o boi que será apresentado durante o festival), é que veremos como se processa as condições e relações de trabalho dessas pessoas, tendo em vista o processo de reestruturação produtiva pela qual o mundo do trabalho passou e continua num constante processo de mudanças.

Segundo a pesquisa, os artesãos são inseridos no trabalho da seguinte forma: trinta por cento foi a convite dos artistas, outros trinta convidados por amigos, vinte por cento a convite do presidente da associação folclórica, e vinte através de familiares. Isso implica que não foram eles que procuraram o trabalho no boi.

Nesse sentido o trabalhador identificado com a letra "B" fala: "Um amigo me perguntou se eu sabia fazer tecido de artesanato. Eu disse que sabia fazer, então ele disse: "umbora” lá comigo? Lá começou a parada e estou lá até agora".

Apesar de todos terem sido convidados a trabalhar, podemos observar que setenta por cento foram contratados pelo boi, os outros trinta foram pelos artistas. No que se refere ao contrato pelo artista denota uma forma de trabalho terceirizado, pois não há vínculo contratual com a associação.

Segundo Braga (2002, p. 100), os artistas plásticos são contratados pelos bois para idealizarem e criarem as alegorias, as fantasias individuais e coletivas, o boi, entre outros. Esse contrato é em média por dois meses, podendo ser mais tempo, dependendo do grau de importância dos chamados artistas de ponta, e no período da pesquisa realizada pelo autor, eles recebiam pelo contrato cerca de quarenta mil reais. Porém, esses artistas não trabalham sozinhos, são 
responsáveis pela contratação de uma equipe que lhes auxiliará nos trabalhos desenvolvidos. Esses auxiliares são de responsabilidade exclusiva dos artistas, isentando os bois-bumbás de qualquer ônus com esses trabalhadores.

Nesse sentido, de acordo com entrevista realizada com o diretor financeiro do Boi-Bumbá Garantido, a contratação dos trabalhadores transcorre da seguinte forma:

Contratados no ano passado com contratos nos galpões foram 384. Mas, não são só essas pessoas que trabalham para o boi. Existe uma série de pessoas que também prestam serviço ao boi, que não são contratados diretamente pela associação, muitos são contratados pelos contratados do boi. Por exemplo: o boi contrata determinadas pessoas, três pessoas para movimentarem a alegoria, da Cidade Garantido para o bumbódromo e depois voltar com as alegorias, depois das apresentações.

Mas, essas pessoas contratam uma série de outras pessoas para fazerem esse trabalho. Então, a serviço do boi, vai mais de 500, aproximadamente 600 pessoas, agora, contratados no ano passado, foram 380 pessoas.

Essa forma de contratação acontece semelhante, no boi-bumbá Caprichoso. Segundo o diretor administrativo a associação proporciona 300 empregos diretos, pelo período de março a junho.

Essa lógica de contratação está em conformidade com as grandes empresas, que atualmente, estão optando por serviços terceirizados, ou seja, contratam outras empresas prestadoras de serviços para suprirem suas necessidades.

Singer $(2003$, p. 24, 25) faz uma comparação entre a relação empresa e empregados e recorda que tempos atrás o empresário empregava toda uma equipe para desenvolver os trabalhos solicitados por ele, e hoje, mudou de configuração, pois, são contratados os serviços de uma empresa prestadora de serviços para executar essas mesmas atividades. O que difere ainda mais é o fato de que a empresa contratante é isenta de todos os encargos sociais com esses trabalhadores, e dessa forma fragiliza o empregado, pois apesar de parecer livre para vender sua força de trabalho, perde todo o direito que possuía. 
Os trabalhadores dos bois-bumbás Garantido e Caprichoso são contratados de duas formas e, além disso, existe diferenciação de quem efetua o pagamento. Os contratos são Contrato Particular de Serviço Prestado/ Temporário que no caso da amostragem são setenta por cento e estes são pagos pelo departamento financeiro do boi; a outra modalidade é de Contrato Verbal/ Temporário, no qual estão inserido 30 por cento dos trabalhadores e quem realiza o pagamento é o artista que o contratou. Todos os trabalhadores, contratados diretos e indiretos, desenvolvem suas atividades nas dependências dos bois-bumbás.

Com referência aos contratos de trabalho, os artesãos comentam: Quem trabalha com contratos nos bois sãos os artistas. É lançada a proposta. É lançada entre artistas e trabalhadores, uma conversa informal, e tudo é acertado ali. (Artesão “G”); Contrato foi a partir de 2007, antes não era assim. (Artesão “E”); Em 2005 foi na responsabilidade do artista plástico, ele ia pagar e pagou. No ano de 2006 o contrato assinado foi com o boi (Artesão "H”).

Esse contexto vivido pelas associações folclóricas e pelos trabalhadores do boi contempla o que Singer (2003), comenta anteriormente, e assim as pessoas que trabalham para o boi e pelo boi, ficam prejudicadas e, como muitas, não possuem nenhum tipo de contrato formal, fica sem ter a quem reivindicar direitos.

Devido a esses acontecimentos é que muitos trabalhadores, depois que termina o festival, ficam sem receber suas remunerações e isso tende a transcorrer em transtornos para ambas as partes, como é verificado na mídia.

O jornal "Amazonas Em Tempo" (2007, p. 3), expõe o problema vivido pelos Kaçauerés (trabalhadores que empurram os módulos de alegorias para o bumbódromo) que cobravam o pagamento pelos serviços prestados ao Boi Garantido e que até o momento não havia sido pago.

Tavares (2004, p. 135), ao referir-se sobre as formas flexíveis de contratação que ocorrem com caráter de legalidade no Brasil, acaba por diminuir os direitos dos trabalhadores, garantido por lei. Nesse sentido, cada vez mais os trabalhadores perdem seus direitos conquistados historicamente e os sindicatos enfraquecem seu poder de luta.

Assim, os trabalhadores são obrigados, pela questão da sobrevivência, viverem e conviverem com formas precarizadas de contratação para o exercício de seu trabalho, tendo que ficar à mercê dos mandes e desmandes 
de um sistema que está em constante reestruturação, e com perda para os trabalhadores. Os mesmos não conseguem acompanhar tal desenvolvimento, haja vista, não possuírem as reais condições para esse embate.

A renda mensal nessa atividade apresenta maior índice na variável de um a dois salários mínimos, o que totaliza sessenta por cento; vinte por cento recebem menos de um salário; dez por cento recebe de três a cinco salários, e dez por cento não informou. Os rendimentos apresentados se referem à remuneração das atividades realizadas para os bois-bumbás.

É detectado entre os entrevistados, vinte por cento que recebem menos de um salário mínimo. Essa modalidade contraria o que preconiza a CLT Consolidação das Leis de Trabalho, no Art. 118: "O trabalhador a quem for pago salário inferior ao mínimo terá direito, não obstante qualquer contrato, ou convenção ao contrário, a reclamar do empregador o complemento de seu salário mínimo".

Dessa maneira é difícil para o trabalhador prover-se do mínimo necessário para a tão chamada cidadania, o que existe de fato são "vestígios de cidadania", plena de obstáculos.

Nesse sentido, Antunes (1995), fala que o produto do trabalho do homem não é usufruído por ele, pois o que o capital considera é que o homem deve apenas se satisfazer com o que pode suprir a sua sobrevivência, que para o sistema é o justo.

Considerado a baixa remuneração que algumas pessoas recebem no trabalho desenvolvido para os bois-bumbás, percebe-se que as associações folclóricas afirmam a lógica capitalista de produção globalizada.

As atividades para as quais os artesãos foram contratados foram as seguintes: auxiliares de alegoria (50\%), auxiliares de tuxaua (30\%), artista plástico de alegoria (10\%), artista plástico de tuxaua (10\%).

O artista plástico de alegoria é chamado de "artista de ponta". Os artesãos que são contratados pelo boi trabalham para esse artista; os contratos realizados pelo artista de tuxaua são de sua responsabilidade. De acordo com os trabalhadores as atividades realizadas são diversas: $\mathrm{O}$ artesão " $\mathrm{A}$ " fala que, faz pastelagem, criação, tudo que aparece; o "B" faz fôrmas de arames, armações de arames; o "C" é coreógrafo e artista plástico; o "D" fala que foi contratado como auxiliar de galpão central, mas, tem que saber fazer de tudo um pouco. Faz tudo que o artista de ponta manda; o "E" faz pastelagem e tudo o que 
precisar; o "F" é ajudante de alegoria; o "G" faz tudo de artesanato; o "H" faz adereço, costura, cortes de pano, colagem, entre outros. Fazia tudo. O "I" corta pena, separa sementes, cola sementes, dá ideias; o "J" é artista plástico de tuxaua.

De acordo com o exposto, percebe-se que o trabalhador do boi-bumbá realiza várias atividades, e ao mesmo tempo há uma separação entre os que idealizam o trabalho e aqueles que desenvolvem. Essa processualidade pode ser percebida na fala de Silva (2002, 01), ao reportar-se a Kosik (1976) quando comenta:

o trabalho assume configurações específicas sob condições sócio-históricas determinadas: se, por um lado, a dimensão teleológica do ser social possibilita ao homem desenvolver e efetivar o seu caráter crítico-transformador, por outro, identifica seus limites nas condições materiais e objetivas da realidade sob as quais o processo de trabalho é realizado, $\mathrm{O}$ capitalismo separa o trabalho da criação, os produtos dos produtores e transforma o trabalho numa fadiga incriativa e extenuante (...). A criação é arte, enquanto o trabalho industrial é ofício, é algo maquinal, repetitivo e, portanto, algo pouco apreciado e que se autodespreza.

Hoje o trabalho desenvolvido pelos trabalhadores que desempenham suas atividades para o boi de Parintins, certamente não está configurado como um trabalho ontológico, um trabalho que realize totalmente aquele que executa o trabalho. Por outro lado, os artistas plásticos de alegoria, que são os artistas de pontas e os demais, como os de tuxaua, ainda conseguem idealizar e objetivar o que será desenvolvido, porém, os demais, somente executam.

Percebe-se que o boi-bumbá de Parintins incorporou a lógica capitalista de produção flexível, polivalente e para tal também precisa de trabalhadores de igual forma. Nesse sentido, os artesãos correspondem fielmente a esta solicitação, pois como os mesmos comentam, "fazem de tudo", tudo o que lhes é programado. Para Tavares (2004, p. 132)

Certamente há muitas ocupações na esfera da estrita sobrevivência, pois por mais que o capital se expanda não absolutiza a vida social; contudo, o crescente 
desaparecimento das regulações que caracterizam o trabalho formal é um forte indício da tendência à generalização do trabalho informal.

O festival folclórico é realizado todos os anos e tornou-se uma opção de trabalho para muitas pessoas da cidade, por isso, anualmente os artesãos retomam as atividades nos galpões.

Conforme informações durante a pesquisa de campo pudemos verificar que o tempo mínimo de trabalho é de dois anos, e o de maior tempo é o de vinte e cinco anos. $\mathrm{O}$ artesão, apesar de trabalhar a anos nas atividades acima mencionadas, o trabalho é periódico, salvo o artista plástico de ponta, pois este é contratado durante o ano todo, com o objetivo de projetar o que será realizado no ano posterior.

Segundo o artista "C", "acaba o festival e você já fica fazendo alegoria". Como já foi anteriormente citado neste capítulo, Braga (2002), comenta que os artistas plásticos são contratados pelos bois para planejarem e idealizarem as fantasias e alegorias que serão utilizadas no festival.

Em relação aos períodos de trabalho desenvolvidos no boi de Parintins, o diretor administrativo da Associação Folclórica Boi-Bumbá Caprichoso, relata:

O período de trabalho corresponde, outubro e novembro, acontece à inscrição e escolha de toadas; de outubro a janeiro é concebido o projeto do boi de arena, escolha do slogan, subtemas, desenhos de alegorias, figurinos, fantasias e lançamento de CD; de março a junho é a execução do projeto do boi de arena, acontece a entrada em galpão e QG's. Os ensaios de tribos e marujadas inicia em março, após a audição de composição do $\mathrm{CD}$; A partir de abril é para o povo em geral.

Tomando por base a fala do diretor administrativo do Caprichoso, podese perceber que a questão da qualificação é um fator primordial para que o trabalhador seja necessário à instituição e, por isso dificilmente descartado. Essa condição é enfatizada por vários autores, como Pochmann (2000), Singer (2003) e Antunes (1995). Decorrente a isso, os trabalhadores são contratados 
por tempos diferenciados, ou seja, um mês, dois meses, três meses, quatro meses, e um ano.

Antunes (1995, p. 41) expõe, que com a reestruturação produtiva o trabalho tornou-se mais especializado, portanto, necessitava de trabalhadores também qualificados. No entanto, o que se observa é uma gama de pessoas que ficaram à margem do trabalho formal, tendo que ser submetidas ao subemprego, ao trabalho precário, informal, temporário, parcial. Portanto, diante exposto anteriormente, os artesãos trabalham em tempos relativamente curtos, para quem necessita de tempo integral de sobrevivência.

Quanto a carga horária diária de trabalho desses trabalhadores, observase que a maioria trabalha por mais de 12 horas, sendo no total de setenta por cento. Os demais afirmam que cumprem apenas o que está no contrato, ou seja, oito horas de trabalho. Inclusive pode-se através da fala de alguns observar se eles consideram a carga horária excessiva, ou não.

O trabalhador "A" fala que: "Tinha vezes quando o trabalho atrasava a gente virava. São oito horas, mais extras. (Recebia pela extra?) Recebia, mas eu anotava. Tinha gente que não anotava. Eu anotava pra esfregar na cara deles na hora de pagar". O "C" trabalha mais de doze horas, porém comenta: "Eu gosto disso". O "D" considera que a "carga horária é muito grande. A gente assina o contrato de oito horas, mas, trabalha mais pra não ganhar hora extra". O "H", fala: "Entrava às 7 h e não tinha hora de sair. Não recebia extra"; e o "J" diz: "Chego a trabalhar de 18 à 20 horas".

Dos entrevistados, cinco consideram sua carga de horário excessiva, os outros não. Diante disso pode-se inferir que esses trabalhadores, que não consideram sua carga de horário excessiva, ainda não deixaram as velhas formas de trabalho no boi e ainda não perceberam que a lógica do sistema capitalista adentrou na festa do boi-bumbá e que eles fazem parte dessa produção.

Segundo Marx e Engels (2002, p. 13), "a burguesia desnudou de sua auréola toda ocupação até agora honrada e admirada com respeito reverente. Converteu o médico, o advogado, o padre, o poeta e o cientista em seus operários assalariados".

Em Parintins, a indústria cultural, através da injeção de investimentos transformou os artesãos dos bois-bumbás também em operários assalariados. 


\section{Segurança do Trabalho}

O presidente da República Itamar Franco, no uso de suas atribuições legais, acerca da Segurança e Saúde dos Trabalhadores e o Meio Ambiente de Trabalho, instituiu o Decreto n. 1.254, em 29 de setembro de 1994. O referido decreto, em seu Art. $1^{\circ}$ consta:

A Convenção n. 155, da Organização Internacional do Trabalho, sobre segurança e Saúde dos Trabalhadores e o Meio Ambiente de Trabalho, concluída em Genebra, em 22 de junho de 1981, apensa por cópia a este decreto, deverá ser cumprida tão inteiramente como nela se contém.

Para que se tenha suporte de comentar sobre condições de trabalho, tendo em vista a segurança do trabalho, é imprescindível verificar o que a lei preconiza acerca de acidentes de trabalho.

De acordo com o Art. 19 da Lei Previdenciária, n. 8.213, de 1975, define que

Acidente do trabalho é o que ocorre pelo exercício do trabalho a serviço da empresa ou pelo exercício do trabalho dos segurados, provocando lesão corporal ou perturbação funcional que cause a morte ou a perda ou redução, permanente ou temporária, da capacidade para o trabalho. Uma outra definição, mais ligada a um critério prevencionista, diz que Acidente de Trabalho é todo fato indesejável, inesperado, não planejado, que interrompe ou interfere num processo normal de trabalho, resultando em lesão, dano material, ou perda de tempo.

Retomando a proposta inicial deste trabalho, que é analisar as condições de trabalho dos artesãos dos bois-bumbás de Parintins, principalmente no interior dos galpões, buscar-se-á conhecer e analisar a dinâmica dessas atividades.

Os materiais utilizados pelos trabalhadores a fim de construir o boi de arena são: cola de sapateiro, cola quente, tinta, tinner, solda, ferro, alicates, faca, tesouras, isopor, tecidos, papelão, materiais regionais diversos, entre outros. 
Observa-se que os artesãos lidam com materiais que podem trazer danos a saúde e, consequentemente, se não for utilizado de maneira adequada, conforme preconiza as normas de segurança do trabalho, pode ocorrer prejuízos para o desenvolvimento das atividades de trabalho e para a vida dos trabalhadores.

Tendo em vista o tipo de material utilizado pelos trabalhadores, a fim de executar a construção das alegorias, das fantasias, entre outros elementos que sãos usados na apresentação dos bois-bumbás, torna-se importante verificar se existe proteção para o trabalho nos galpões, nos QG's, ateliês, e em qualquer dos locais aonde são desenvolvidas as atividades referentes ao boi.

A metade dos artesãos assinala que no local onde são realizadas as atividades existem os EPI's - Equipamento de Proteção Individual, e a outra metade que não existe, inclusive o trabalhador "G" relata que, "só existe a proteção de Deus". Da metade que afirmou existir equipamento no local de trabalho, nem todos utilizam a proteção.

O motivo pelo qual não utilizam os EPI's são os seguintes: afirmam não usarem por não existir no local de trabalho, ou que incomodam, outros não usam por esquecimento e também por não dar importância, outros, que há risco por ser um trabalho de médio porte. O "D" diz que "algumas vezes deram pra gente umas luvas e máscaras. Irrita e não protege nada, não é adequada. A fumaça da solda atravessa".

No que tange à utilização dos EPI's pelos colegas de trabalho observase na fala dos artesãos: "A", comenta: "O máximo de proteção que tem ali é o capacete do soldador. Às vezes eles nem usam, só fazem virar a cara". O "B" fala que seus colegas utilizam proteção, porque "trabalham em coisas mais fortes do que eu, não considero meu trabalho perigoso".

Em relação ao Equipamento de Proteção Individual os Diretores das Associações Folclóricas Boi-Bumbá Garantido e Caprichoso relatam:

Embora o festival esteja em sua $42^{a}$ edição, nossa associação ainda está em processo de estruturação. Estamos trabalhando a conscientização da utilização dos materiais de segurança no período de trabalho em galpão, embora seja um trabalho inicial. Porém, temos o objetivo de atuar com 
um profissional técnico de segurança em nossas instalações em 2007 (diretor administrativo do Caprichoso 2007).

Há preocupação com a segurança para o trabalho. Muito embora, hoje, nós ainda não tenhamos atendido esse item em sua plenitude. Nós temos que providenciar o EPI, que compõe normalmente de um capacete, óculos para quem trabalha soldando, ou dentro do galpão que tem poeira e fuligem, luvas, macacão, botas, avental. Então, essa questão do equipamento individual, eu considero que nós ainda estamos deixando a desejar (diretor financeiro do Garantido: 2007).

Observa-se que os EPI's representam um desafio, tanto para as Associações Folclóricas, quanto para os trabalhadores, pois as associações ainda não estão acompanhando o que preconiza a lei de segurança do trabalho e, por outro lado, muitos trabalhadores, apesar existir no local de trabalho os equipamentos, ainda não utilizam.

Essa questão, em relação aos trabalhadores passa por um trabalho de educação para que os mesmos visualizem nessa proteção o meio de prevenir acidentes. No Capítulo V, da segurança e da medicina do Trabalho, na Seção IV, do Equipamento de Proteção Individual, Art. 166 consta que:

a empresa é obrigada a fornecer aos empregados, gratuitamente, equipamento de proteção individual adequado ao risco e em perfeito estado de conservação e funcionamento, sempre que as medidas de ordem geral não ofereçam completa proteção contra riscos de acidentes e danos à saúde dos empregados.

Segundo Pochmann (2000, p. 47) devido a instabilidade do mundo trabalho, a precarização das condições e das relações de trabalho e a permanência das elevadas taxas de desemprego devem ser referidas ao movimento do capitalismo contemporâneo neste final de século (e início do século XXI completada pela pesquisadora), que ocorre desprovido de uma coordenação favorável à produção e ao emprego para todos, entre os principais países avançados. 
Diante das colocações feitas pelo autor e tendo em vista as condições de trabalho nos galpões dos bois-bumbás de Parintins, como também a fala da diretoria dos bumbás, visualiza-se uma situação de inadequação à nova realidade econômica.

O mundo capitalista em constante reestruturação produtiva solicita trabalhadores e empresas que correspondam à solicitação do capital, que é prover lucros. Dessa forma é que anualmente, empresas nacionais e multinacionais, assim como também o Governo Estadual e Municipal investem nesta grandiosa festa, a fim de ter retorno satisfatório.

Quanto a terem sofrido ou conhecerem alguém que tenha sofrido qualquer tipo de acidente durante a realização de suas atividades no galpão dos bois-bumbás Garantido e Caprichoso, setenta por cento dos trabalhadores confirmam os acidentes, e vinte por cento dizem não ter conhecimento do fato. Os tipos de acidentes apontados pelos artesãos foram diversos: incêndio de alegorias, choque, queda de alegoria, furadas, cortes e até mesmo mortes.

Um dos entrevistados ressalta também acidentes com morte no transporte das alegorias. Complementando a fala do trabalhador " $\mathrm{H}$ ", acerca da queimadura, comenta:

Eu sofri. Na hora do acidente eu sofri uns ferimentos, e o meu marido também. Foi com fogo. Queimadura de tiner. O motivo foi o tiner que jogaram e explodiu a alegoria. Pensando que era água que o rapaz jogou para apagar o fogo e era o tiner.

Segundo o relato dos entrevistados, são freqüentes os acidentes durante o trabalho. O evidente, é que esses casos de acidentes ocorrem há muitos anos sem que seja tomada nenhuma medida. Somente nesses últimos anos os órgãos competentes têm cobrado das associações folclóricas providencias a esse respeito. Nesse sentido o diretor financeiro do Boi-Bumbá Garantido comenta:

Recentemente, numa revisão do Ministério do Trabalho, feito no nosso galpão, recomendou que nós tivéssemos que colocar exaustores nos galpões, a fim de melhorar a qualidade do ar. Que nós tivéssemos de fazer portas de 
saídas de emergência, reparo nas instalações elétricas, a fim de evitar o perigo de um curto circuito e consequentemente de um incêndio e que nós providenciássemos a melhoria dos banheiros e vestuários. E que providenciássemos a complementação do equipamento de proteção individual. Há de resolver, também muitas vezes o trabalhador resiste. Muitas vezes ele não quer fazer a coisa porque ele acha que fica muito quente ficar de macacão, de bota, de luva, de capacete [..] nós temos que melhorar, até para cumprir o que determina o Ministério do Trabalho, da Delegacia Regional e Municipal.

Esse aspecto foi comentado somente pelo diretor do Boi Garantido, haja vista a associação ter convivido com essa realidade mais acentuadamente.

Acerca dos acidentes, os artesãos relatam que setenta por cento dos trabalhadores receberam assistência. Destes, sessenta por cento foram assistidos pelo boi, e dez por cento ficou por conta do próprio artista de capacete; dez por cento dos acidentados não recebeu nenhum tipo de assistência. Os demais afirmam não ter conhecimento de nenhum fato.

Ao pontuar a respeito da assistência oferecida pelo boi-bumbá, o entrevistado "J" fala da dinâmica desse atendimento: "A assistência é oferecida pelo boi, que conta com pessoas para o socorro e encaminha para hospitais próximos".

O que recebeu assistência do artista de capacete e não do boi, condiz com o que já foi citado anteriormente, acerca da contratação dos trabalhadores. Alguns são contratados por artistas contratados do boi, por esse motivo esse trabalhador não recebeu assistência do boi, e sim, do artista. Essa modalidade caracteriza a terceirização dos serviços e em consequência a fragmentação das relações de trabalho.

Apesar de esse trabalhador prestar serviços nas dependências do boi, não pode usufruir nenhum tipo de proteção. Dessa maneira, vivendo e convivendo com formas precarizadas de trabalho, sem ter subsídios de contribuir com a Previdência, para que mais tarde possa gozar de direitos como a aposentadoria, esse trabalhador tende a ser futuro usuário da assistência social. 
Valorização do trabalhador

Segundo Lessa (1997:p.11), o trabalho é a categoria fundante do ser social, pois, é através dele que o homem pode transformar a natureza e transformando-a transforma também a si próprio, pois, só o ser humano tem essa capacidade, por ser um ser ontológico, um ser social

Portanto, é pelo trabalho que o homem pode atingir objetivos previamente idealizado. Porém, hoje, essa objetivação está cada vez mais distante da realidade da "classe-que-vive-do-trabalho". A reestruturação produtiva podou essas possibilidades e lançou grande parte do trabalhador no mercado de trabalho em busca de sua sobrevivência.

Partindo desse pressuposto, e buscando na vivência dos trabalhadores dos galpões dos bois-bumbás de Parintins, de como eles se veem na realização dessas atividades, inicialmente buscou-se verificar, se existe algum tipo de incentivo por parte das associações para melhorar a qualidade do trabalho desenvolvido. Essa questão pode ser sentida na fala de alguns dos artesãos: $\mathrm{O}$ trabalhador "A" fala que:

Não existe nenhum incentivo pela parte do boi, mas, pela parte do artista. Já que ele não pode dar o pagamento que a gente merece, faz o máximo pra deixar a gente à vontade. Paga lanche, isso dependendo do artista, não é todo artista que faz isso. Se a gente ficar mais tempo ele paga até o almoço. Mas nem todos pagam.

O trabalhador "C", diz que "o boi está avançando neste lado". O "D", comenta: "O presidente promete, promete, mas, nem aparece no galpão". O "G" fala que, "o sonho de todo pessoal é que a diretoria do boi veja o teu trabalho". Segundo o trabalhador "J", acontecem oficinas de arte, palestra, e pesquisas. Então, dos entrevistados, observa-se que quarenta por cento dizem não se sentir valorizado no trabalho, porém, os demais se colocaram em contrário a essa posição. Nesse sentido, o diretor financeiro do Boi Garantido, comenta:

Nós temos anualmente diversos cursos, porque o Garantido ao longo desses anos mantém um convênio com a Força 
Sindical [...] de trazer ao Município de Parintins diversos cursos. Curso de inglês, espanhol, digitação, motorista de táxi, serralheiro, soldador, pintor, desenhista, escultor [..] São em cada ano uma base de dez cursos, 25 pessoas em cada curso, o que atinge normalmente duzentas e cinqüenta pessoas cursando, treinando na escolinha do boi. Normalmente as pessoas que trabalham pro boi, vêm desses cursos e são escolhidos pelos artistas de ponta. São chamados de artistas de ponta os chefes de equipe. E eles formam as equipes deles. Sugerem mandar pessoas pro boi e são essas pessoas que recebem esse preparo.

O diretor administrativo do Caprichoso, diz que muitos também vieram da escolinha do boi. Segundo ele, "o desenhista do Conselho de Arte era da escolinha, inclusive o Júnior Paulain”. O ultimo citado pelo diretor, trata-se do atual apresentador do boi.

No que tange aos artesãos que afirmam não existir incentivo por parte das associações podemos inferir que se trata daqueles que se pode caracterizar como trabalhador terceirizado. Nesse sentido Silva (2002, p. 4) comenta que “para esse 'novo' trabalhador que perde seus antigos direitos e se insere de forma funcional no novo paradigma tecnológico, resta tornar-se desempregado, marginalizado ou trabalhar sob novas formas de trabalho e qualificação”.

Assim, muitos dos trabalhadores que desenvolvem suas atividades para os bois-bumbás acabam por legitimar as formas de trabalhos precarizadas. Pois, de outra maneira estarão fora do mercado de trabalho, aumentando com isso o contingente de trabalhadores sem ocupação e emprego decorrente da fragilidade que o município de Parintins apresenta em alternativas de trabalho, como foi comentado anteriormente.

Quanto ao se sentirem valorizados no trabalho desenvolvido nos galpões dos bois, verificamos que oitenta por cento afirmam se sentirem satisfeitos quanto à valorização, porém podemos sentir na fala de alguns dos artesãos que mesmo na afirmativa do questionamento deixam transparecer de alguma forma a insatisfação: Artesão "A": "Sim. Por outro lado, eu sou considerado orelha do artista plástico. O que eu aprendi na escolinha não tem nada a ver com o meu trabalho". Artesão "D": 
Não. Eles nunca me ajudam, só querem pra eles. Você fica até fora do bumbódromo porque eles dão as camisas pro pessoal de fora. O boi não dá prioridade pros trabalhadores. São três meses que você esquece sua família, você vai porque gosta e ele não vê esse lado. Eles gritam.

Já vem projetado da Comissão de Arte, já vem tudo desenhado pra gente montar. Mas, se uma coisa não está legal, a gente fala com o artista, ele vai à Comissão, se aprovar, aí já fica a nossa ideia. É bom pra nós.

Ao observar a fala dos trabalhadores, verifica-se que a maioria se sente valorizada em seu trabalho, no entanto, essas pessoas vivem em situação de exploração, sem ter consciência disso. A ideologia que perpassa no interior das fábricas, levando o operário a cooperar com o aumento da lucratividade das empresas, dando ideias, trabalhando além da função para qual foi contratado, excedendo o horário de trabalho, aliás, sendo um trabalhador polivalente, flexível, condiz com o apresentado pelos artesãos que trabalham para as associações dos bumbás de Parintins. Diante dessas assertivas Silva (Id: p.5) comenta, que ao acreditarem usar da reflexão, e a criatividade, "pode significar uma estratégia de defesa assumida pelos pesquisados que, impregnados pela ideologia empresarial e pelo permanente pavor do desemprego, 'inserem' elementos qualitativos ao seu trabalho como forma de autovalorização".

Nessa direção pode-se analisar como a valorização no trabalho pode ser sentida pelos trabalhadores do boi-bumbá. O que se percebe é a grande necessidade que essas pessoas têm em ser reconhecidas e valorizadas em seu trabalho.

\section{A importância do trabalho desenvolvido nos galpões dos bois-bumbás Garantido e Caprichoso para os artesãos na realidade de Parintins}

O trabalho desenvolvido pelos artesãos nos galpões dos bois-bumbás Garantido e Caprichoso, quanto a sua importância, é vista de vários ângulos. Para tal, tornou-se necessário pontuar a fala de cada um dos entrevistados.

Em relação aos benefícios que as atividades desenvolvidas trazem para a vida desses trabalhadores são os seguintes:

O trabalhador " $\mathrm{A}$ " aponta que não traz nenhum benefício. "A não ser as amizades. (Você não consegue fazer nada com esse dinheiro?) Não, é muito 
pouco". O entrevistado "B" diz que "dá para o sustento da família e pra pagar aluguel"..

$\mathrm{O}$ "C" comenta que:

Eu tenho minha casa, eu tenho a minha vida, a minha família, eu tenho orgulho, eu tenho minha vaidade conduzida com equilíbrio. Eu tenho amigos que são oftalmologistas, cardiologistas, da mesma geração que eu. Dizem: Poxa [...] eu segui a minha carreira, mas quando eu vejo que tu fez muito mais pela minha cidade do que eu, quando eu vejo o seu nome no Salgueiro [...] ir para o Sul do País, sabendo que há uma discriminação e que os índios do Amazonas deram um show, ganharam o carnaval em São Paulo, no Rio de Janeiro, em Manaus e continuam. Quando eu vejo o Jairzinho, o Rocy, carnavalesco como eu, firmando em São Paulo, é um prêmio. Isso é o valor maior, o reconhecimento. Isso vale a pena viver. [...] Eu fico feliz por ser filho de Parintins, um picolezeiro, que veio do bairro de Palmares, de ter construído uma história.

O artesão "D”, fala: "Pra falar a verdade, não traz muito benefício. Só as pessoas como eles lá que ganham quinze a vinte mil pra lá, já dá pra aparecer benefícios". Quando ao artesão "E” "traz emprego. É difícil na cidade, é como consigo algum dinheiro".

Nesse sentido o artesão " $F$ ", relata:

Traz benefício, não só, pra mim, mas, pra toda minha família. Eu ajudo a criar o meu sobrinho, minha mãe que tem problema de saúde, e ao meu próprio filho. Essa valorização que eu digo, uma importância e um valor porque nesse momento que eu entrei no boi, não só no boi, mas no carnaval, eu aprendi muita coisa, a sair da perdição. No momento eu era um rapaz perdido, andava por ai quebrando garrafa na rua. Eu era um desordeiro. Aí trouxe uma valorização imensa pra mim.

O "G", acerca deste assunto comenta: 
Eu tô fazendo uma coisa que eu gosto de fazer e que futuramente se você se empenhar em fazer isso, lhe renderá frutos. O único benefício que eu vejo é aprender uma coisa que eu sonhava aprender e eu estou aprendendo.

Você não pode construir um castelo com o que você ganha. O pouco que você ganha, você vai levando a vida como Deus dá.

O trabalhador "H" fala que "com o dinheiro que a gente consegue lá, como a gente mora de aluguel, paga o aluguel e dá pra ajudar os meus filhos que não vivem com a gente". O "I" considera que dá pra comprar "muita coisa boa pra casa"; e pro "J" traz "prazer mental, e conclusão do trabalho".

Portanto, apesar da precariedade que esse trabalho apresenta, os trabalhadores conseguem ter algum tipo de realização, se não for pelo lado financeiro, mas alguns dizem que a satisfação pessoal é válida. Porém, é importante lembrar que o trabalho é o meio pelo qual o homem se objetiva e traz o seu sustento e de sua família.

Segundo o relato dos trabalhadores acerca dos benefícios que a realização das atividades pro boi, traz para sua vida, a maioria considera que de alguma forma, pela oferta escassa de trabalho no município, esse trabalho acaba por ser uma opção de renda para muitas pessoas. Mesmo com toda essa precariedade é necessário trabalhar e como a cidade não oferece trabalho formal para todos os moradores o que resta é submeter-se ao que aparece, pois muitos desses trabalhadores não suprem as exigências do mercado.

Quando termina o Festival Folclórico em Parintins as pessoas que trabalham para as associações folclóricas Garantido e Caprichoso passam a realizar outras atividades. Alguns têm emprego fixo, porém, outros ficam à mercê de trabalhos alternativos, como é o caso do artesão "B", que vai para o interior trabalhar na roça (plantio de macaxeira, mandioca, entre outros), até que chegue a época de ser chamado para trabalhar novamente para o boi.

Existem aqueles que são chamados para trabalhar como artesãos em outros eventos dentro ou fora do Estado e até mesmo fora do País, como por exemplo, o "C" comenta:

Eu sou um artista sazonal, inspirado em Jair Mendes. Uma hora você é chamado pra dar suporte logístico num evento, outra hora tem que fazer um projeto. Acaba o festival, vou 
fazer o andor da santa, é uma doação. Acabou, você vai pra Manaus e interage com todas as ações, o Boi Manaus, o Natal. A nossa agenda de eventos é muito preenchida. A toda hora chamam a gente pra ir pra São Paulo, Manaus. Há quatro anos eu não ia a esses lugares. Agora, esse ano foi feito um trabalho na Coca-Cola. Fui chamado e eu aceitei.

Nesse sentido Singer (1995) considera que os pobres não podem se dar ao luxo de ficar desempregados, aliás, o autor reconsidera essa afirmativa e diz, que na realidade o máximo que podem fazer é ficar parados, no entanto, precisam buscar alternativas de ocupação para sua sobrevivência, Além dessa situação, que não é nova para quem é pobre, pois segundo o autor as mudanças ocorridas decorrentes da terceira revolução industrial não os afeta diretamente, o que na verdade se apresenta como obstáculo para novas ocupações é a concorrência com os novos desempregados que oriunda da antiga classe média.

Então, verifica-se na realidade desses trabalhadores dos bois-bumbás de Parintins, que grande parte não possui muitas opções de empregos e, ainda tem que conviver com a realidade de muitos que também trabalham como artesãos do boi e têm empregos paralelos a estas atividade.

Grande parcela dessas pessoas encontra-se desqualificadas para disputarem, o mercado de trabalho e nesse sentido Antunes (1995), Pochmann (2000), Singer (2003), Tavares (2004) concordam que, as relações e condições de trabalho tornaram-se fragmentadas e nesse contexto o trabalhador, tanto formal, como o informal tende a conviver com formas de trabalho precarizados.

A respeito do que os artesãos seriam capazes de fazer para que seu boi de preferência fosse campeão, verificamos:

\begin{tabular}{|l|l|}
\hline Entrevistados & Falas \\
\hline A & Trabalho, somente. Não trabalharia de graça. \\
\hline B & Muita coisa. Trabalharia de graça, só pela experiência. \\
\hline C & $\begin{array}{l}\text { Tudo, só não da antiética, mas da ousadia. Eu faria de limpar o galpão } \\
\text { a construir a melhor alegoria, de empurrar a alegoria, apesar de não ser } \\
\text { minha função. É uma paixão desmedida com equilíbrio. }\end{array}$ \\
\hline D & Ajudar muito, pro Garantido sair bonito, perfeito. \\
\hline E & Trabalharia de graça, por amor ao Boi Caprichoso. \\
\hline
\end{tabular}




\begin{tabular}{|l|l|}
\hline F & $\begin{array}{l}\text { Faria de tudo pelo meu boi. Montava uma estrutura enorme, faria de } \\
\text { tudo pro meu boi voltar a ganhar. }\end{array}$ \\
\hline G & $\begin{array}{l}\text { Eu acho que nem tudo você consegue fazer, mas, o mais importante é } \\
\text { mostrar trabalho. Pro meu boi ganhar faria muitas coisas. }\end{array}$ \\
\hline H & $\begin{array}{l}\text { Ai meu Deus do céu, eu não sei o que eu faria. O meu boi é vermelho } \\
\text { e branco. }\end{array}$ \\
\hline I & Deveria ter mais união. \\
\hline J & $\begin{array}{l}\text { Trabalharia de graça. Eu me sinto realizado em trabalhar pro } \\
\text { Garantido. Eu gosto de trabalhar no que faço. }\end{array}$ \\
\hline
\end{tabular}

Fonte: Pesquisa de campo realizada em 2007.

wDiante do posicionamento dos entrevistados podemos verificar que é grande o desejo de que seu boi-bumbá de preferência seja campeão, porém somente trinta por cento se colocaram à disposição de até mesmo trabalhar de graça, porém, a necessidade de reconhecimento do trabalho realizado é maior que o amor pelo boi. Esse anseio por parte dos trabalhadores denota também a necessidade de ascensão no boi, de poder chegar no patamar dos artistas de ponta. Como já foi citado por alguns trabalhadores, a remuneração e o reconhecimento são diferenciados para os que desenvolvem os projetos junto com o Conselho de Arte do Boi e aqueles que executam o projeto. Nesse sentido, como já falou um dos artesãos, isso depende do esforço do próprio trabalhador.

As assertivas anteriores confirmam a fala de Silva (2002: p. 5), ao comentar acerca dos trabalhadores do chão de fábrica da Zona Franca de Manaus que:

Ao consumirem a possibilidade de ser expurgados do mercado de trabalho como uma responsabilidade que thes é absolutamente exclusiva, os trabalhadores legitimam as relações de poder instituídas e ratificam que os conteúdos conceituais entre o trabalho, esforço e qualificação indica uma assimilação coletiva que reduz equivocadamente o 'esforço' individual entre os "capazes" e os "incapazes".

Acerca do significado do Festival Folclórico para a cidade e para a vida dos próprios entrevistados, verifica-se que na visão de todos os artesãos é um acontecimento que propicia o crescimento econômico para a cidade, pois a 
população de Parintins tem alternativas de renda, a melhoria da infraestrutura, valorização e reconhecimento do trabalho desenvolvido pelas associações folclóricas.

Essa satisfação podemos observar no comentário do artesão “D”: É uma coisa maravilhosa pra nós parintinenses. É o orgulho da gente este festival que atrai muita gente. É por isso quando nós estamos ali lutando, fazendo alegoria pra mostrar o que a gente sente, traz muita alegria.

Diante do exposto é importante verificar como os artesãos visualizam a questão de os Bois-bumbás conservarem ou não a sua essência. Acerca deste questionamento verificamos torna-se imprescindível sentir o que cada um pontua sobre esta questão:

\begin{tabular}{|l|l|}
\hline Entrevistados & Falas \\
\hline A & $\begin{array}{l}\text { Não conservam mais. Antigamente antes de pegar fama era algo } \\
\text { muito provinciano. Todo mundo gostava. Era algo que falava sobre } \\
\text { o caboclo. Agora não. Agora até astronauta já está no meio. Não tem } \\
\text { mais nada a ver, perdeu a essência. Todos dois estão assim. }\end{array}$ \\
\hline B & $\begin{array}{l}\text { As tradições são mantidas e precisam ser mais executadas, porque é } \\
\text { a grande referência de cultura de um povo. Isso não impede que essa } \\
\text { essência se confunda com o moderno. }\end{array}$ \\
\hline C & Conserva sim. \\
\hline E & Não conservam a sua essência. Estão iguais ao Carnaval. \\
\hline F & Os dois bois ainda conservam a tradição. \\
\hline G & $\begin{array}{l}\text { O Garantido conserva mais do que o Caprichoso. Eles colocam brilho } \\
\text { demais. }\end{array}$ \\
\hline H & Não perderam. Eles mostram a realidade e a originalidade. \\
\hline I & Mudou muito, eu gosto da raiz e ela não existe. \\
\hline J & Algumas vezes sim, outras não. Esquecem a tradição do boi. \\
\hline
\end{tabular}

Fonte: Pesquisa de campo realizada em 2007.

É notório o sentimento que os artesãos dos bois nutrem a respeito da essência dos bois, pois mesmo que afirmem que ainda seja conservada, percebemos que há uma certa contradição de sentimentos acerca do assunto e 
a preocupação quanto as mudanças.

$\mathrm{Na}$ hipótese deles trabalharem para o outro boi, ou seja, para o boi contrário, noventa por cento afirmam não haver problemas em desenvolver suas atividades, afinal, o que conta, segundo eles, é o profissionalismo e o retorno financeiro que isso pode trazer.

Pode-se inferir na análise desses dados é que mesmo os trabalhadores demonstrando amor à cidade, aos bois de preferência e anseio de lutar pela ascensão de ambos, o apelo pela sobrevivência é maior que tudo isso.

O fato é que, num mundo capitalista no qual o apelo ideológico de igualdade lança os trabalhadores em busca de formas de sobrevivência cada vez mais criativas e sem dúvida neste item os artesãos do boi são insuperáveis, no contraponto desta questão a precariedade de direitos e a exploração de mão de obra também são visíveis e ao mesmo tempo camuflada.

Porém, para esses artesãos, o fato de estarem fazendo parte da construção, como eles falam, "do maior festival folclórico do mundo", os faz sentirem parte importante e necessária à essa construção. Nesse sentido, verifica-se que para eles, destacar a cidade, o festival folclórico, é evidenciar a eles próprios, pois, eles se sentem a própria alma deste evento e deste lugar.

\section{Considerações finais}

A reestruturação produtiva, a globalização, e a flexibilização do trabalho mudaram a dinâmica da vida das pessoas em geral. Novas relações de trabalho, pautadas em antigas formas de trabalho, foram adequadas à ideologia do sistema capitalista contemporâneo. Culturas foram transformadas em produtos e homens livres, em produtores sem as reais condições para consumir.

Parintins, através do festival folclórico se inseriu nessa realidade, cooptada pela ideologia da indústria cultural. Dessa forma se vê a história ser transformada a fim de se conformar ao modelo estabelecido. O boi-bumbá, durante a apresentação fica perdido entre tantos itens, e de outro lado os integrantes do auto do boi resistem ao total descaso de sua existência. $\mathrm{Na}$ realidade a figura do boi foi trocada, em importância, pela figura do pajé.

Porém, não é esse o eixo de análise desse trabalho. O que importa é visualizar o que de fato essa pesquisa trouxe de relevante para essas considerações, que é a condição de trabalho do artesão do boi-bumbá. Nesse 
sentido percebe-se que a caminhada para a efetivação de melhores condições para o trabalhador está longe de ser priorizada. Os constantes acidentes de trabalho ceifam a vida de tantos que se doam para o engrandecimento deste evento, sem que haja de fato uma preocupação por parte dos dirigentes com a melhoria de vida dessa população. Se houvesse essa preocupação, não se precisaria brigar para receber seus proventos.

Percebe-se que a desigualdade social e econômica paira sobre esse trabalhador, assim como nos do mundo capitalizado em geral. A condição de trabalho tende a influir na condição de vida dessas pessoas.

Dessa forma, ao revelar o significado desse trabalho para a vida desses trabalhadores, verifica-se que o que importa para ele, além da questão financeira para a sua sobrevivência é ser valorizado e reconhecido como artista e artesão, que acima de executar tarefas, considera que é capaz também de idealizá-las.

Como afirma Marx e Engels (2002), a burguesia tira essas possibilidades, ou seja, a possibilidade de criar. Podemos afirmar, que o homem por natureza é um ser criativo, pois se não fosse assim, não criaria alternativas de sobrevivência. No entanto, seria leviano afirmar que, o Festival Folclórico de Parintins traz somente degradação para quem vive do trabalho no boi, principalmente aquele que constrói o boi de arena.

É relevante verificar que muitos jovens deixam uma vida em situação de risco, para desenvolverem seu potencial artístico, e através dele buscar possibilidade de ter pelo menos uma ocupação rentável.

É importante perceber que ao observarmos a dinâmica de trabalho dessas pessoas verificamos que além da aparência, que são as dificuldades nesse trabalho desenvolvido nos galpões, por outro lado, e essencialmente, é vislumbrar que o trabalho ainda é fonte de realização.

Porém, sabemos que a ideologia vigente é manipuladora, cria situações de legitimação de domínio e sem perceber o trabalhador com o intuito de ajudar o boi acaba por se lançar no contingente de trabalhador precarizado.

No entanto, é difícil se perceber explorado, pois na dinâmica de vida do dia a dia convivemos com situações alheias ao nosso controle, porém é preciso ficar alerta aos engodos que o sistema nos prega e assim buscar a efetivação dos direitos de todo trabalhador, mesmo trabalhando em formas desreguladas de trabalho.

Apesar de as condições de trabalho dos artesãos dos bois-bumbás 
estarem caminhando para a possível legalidade, destaca-se a valorização que esses trabalhadores têm pela sua terra, e que o amazonense aprenda a valorizar o que é seu, assim como o parintinense faz com tanta sabedoria.

\section{Referências}

ANTUNES, Ricardo. Adeus ao trabalho? Ensaios sobre as metamorfoses e a centralidade do mundo do trabalho. 3. ed. São Paulo. Cortez, 1995.

BRUSCHINI, Cristina. Teoria crítica da família. In: AZEVEDO, Maria Amélia. GUERRA, Viliane A. (org). Infância e violência doméstica: fronteira do conhecimento. 3. ed. São Paulo: Cortez, 2000.

BRAGA, Sérgio Ivan Gil. Os bois-bumbás de Parintins. Rio de Janeiro: Funarte. Editora Universidade do Amazonas, 2002.

BRASIL, IBGE. Cadastro Central de Empresas 2003. In: www.ibge.com.br. Página visitada em 23/1/2007.

BRASIL, IBGE. Resultados da Amostra do Censo Demográfico 2000. In: www.ibge. com.br. Página visitada em 23/1/2007.

CONSTITUIÇÃO FEDERAL, CONSOLIDADAÇÃO DAS LEIS DO TRABALHO, LEGISLAÇÃO TRABALHISTA E PREVIDENCIÁIA. Org. Nelson Mannrich: Obra coletiva de autoria da Editora Revista dos Tribunais, 5. ed. rev. e ampl. São Paulo: RT: 2004.

JORNAL AMAZONAS EM TEMPO. Parintins 2007, B3, 3/7/2007.

LESSA, Sérgio. A centralidade ontológica do trabalho em Lukács. In: Revista Quadrimestral de Serviço Social, ano XVII - n. 52. Editora Cortez, São Paulo: 1997.

MARX, K \& ENGELS, F. O manifesto comunista. Rio de Janeiro, 10. ed. Ed. Paz e Terra: 2002.

POCHMANN, Marcio. O trabalbo sob fogo cruzado. 2. ed. São Paulo, Contexto: 2000.

SILVA, Márcia Perales Mendes; VALLINA, Kátia de Araújo Lima. O assistente social e as mudanças no mundo do trabalho. Manaus, Edua: 2005. 
SILVA, Marcia Perales Mendes. "Significados do trabalho: a voz do trabalhador do chão de fábrica da Zona Franca de Manaus". In: Anais do VIII Encontro Nacional de Pesquisadores em Serviço Social. Associação Brasileira de Ensino e Pesquisa em Serviço Social. Juiz de Fora: ABEPSS, 2002 (CDROM Estúdio Derech Or/ Stúdio Films) .

SINGER, Paul. Globalização e desemprego: diagnóstico e alternativas. 4. ed. São Paulo, Contexto: 2003.

TAVARES, Maria Augusta. Os fios (in) invisiveis daprodução capitalista: informalidade e precarização do trabalho. São Paulo, Cortez: 2004. 